\title{
Aquatic macrophytes in Doñana protected area (SW Spain): An overview
}

\author{
P. García Murillo ${ }^{1}$, R. Fernández Zamudio ${ }^{1}$, S. Cirujano $^{2} \&$ A. Sousa ${ }^{1}$ \\ ${ }_{1}^{1}$ Departamento de Biología Vegetal y Ecología. Facultad de Farmacia. Universidad de Sevilla. Apdo. 874. \\ E-41080 Sevilla. Spain.pgarcia@us.es, rzamudio@us.es \& asousa@us.es \\ ${ }^{2}$ Real Jardín Botánico, CSIC. Plaza de Murillo 2. E-28014-Madrid. Spain. santos@ma-rjb.csic.es
}

\begin{abstract}
A big portion of the Doñana protected areas corresponds to wetlands; in them aquatic macrophytes are the main primary producers and play also other important ecological functions. Nevertheless, they are inconspicuous organisms and their importance in these ecosystems does not seem to be well reflected in the bibliography about this natural area. This paper reviews the most significant information gathered about this group of organisms in this protected area, provides an updated catalogue of this group of plants, and offers some considerations related with this topic.
\end{abstract}

Key words: Doñana, aquatic macrophytes, aquatic vegetation, SW Europe.

\section{RESUMEN}

Una gran parte de los espacios protegidos de Doñana corresponde a humedales, en ellos los macrófitos acuáticos son los principales productores primarios, realizando además otras importantes funciones ecológicas. Sin embargo, son organismos poco conspicuos y su importancia en estos ecosistemas no parece estar reflejada en las publicaciones existentes relativas a este espacio natural. Este artículo recopila la información más significativa sobre este grupo de organismos en este espacio protegido, proporciona el catálogo actualizado de este grupo de vegetales y ofrece algunas consideraciones relativas al tema.

Palabras clave: Doñana, macrófitos acuáticos, vegetación acuática, SW Europa.

\section{INTRODUCTION}

A large portion of the Doñana protected area (Fig. 1) is composed of wetlands. In these ecosystems, aquatic macrophytes are responsible for most primary production and also play an important role in increasing ecosystem structures or recycling nutrients and elements. Aquatic macrophytes are, therefore, key elements in this paradigmatic natural area. Moreover, flora is one of the best natural sources of information regarding current and potential conservation in any natural place. The scarce number of studies on this conspicuous group of organisms is thus surprising.

When the last Doñana Floristic Catalogue was published twenty-five years ago (Castoviejo et al., 1980), it was quite thorough at that time; however, the bulk of new floristic records since then have been aquatic plants (as shown in this

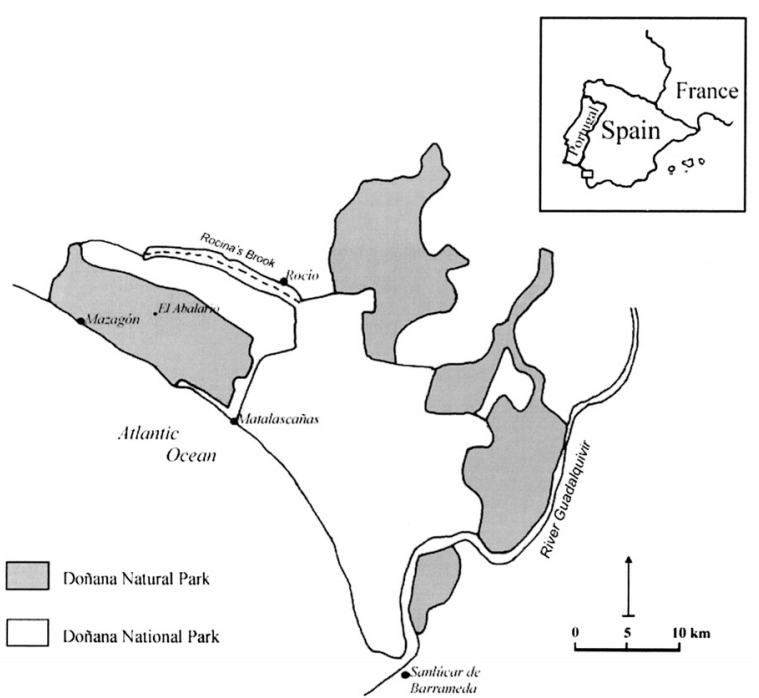

Figure 1. Location of Doñana protected areas. Localización de los espacios protegidos de Doñana. 
paper). This indicates how little is known about aquatic plants in this area.

This is coupled with the fact that some significant environmental events have occurred in this same time period, an increase in intensive agriculture in the area, increased tourism in bordering areas, overexploitation of ground waters, invasions of exotic species, global warming, etc.

All of these issues point to the need to update the information related to the aquatic macrophytes in the Doñana protected area, which is the aim of this paper.

\section{FIRST STEP: CATALOGUING}

Unlike the cases of other places of great natural value in the southern Iberian Peninsula, such as the Sierra Nevada or Sierra de Grazalema, which were prospected by botanists during the nineteenth century or before, the first studies on Doñana's flora appear much later in the mid-twentieth century. In 1945 C. Vicioso, an Aragonese botanist, published a list of taxa collected in the south part of the Huelva Province, but among these references there was no data on macrophytes. It was not until 1967, when references to aquatic macrophyte were found, that seven aquatic macrophytes were cited in an invertebrate catalogue (Mazaranov, 1967) for Guadalquivir Marshes (belonging to Doñana). Cabezudo later began the systematic study of flora in this preserved area, including 18 species of aquatic macrophytes in his studies (Cabezudo, 1974; 1975; 1978, and Galiano \& Cabezudo, 1976). In 1981, some years later, the brilliant work of Castroviejo et al. (1980) completed the information compiled by Cabezudo, nearly completing the list of vascular plants in Doñana National Park. In subsequent years this Catalogue has changed very little, with the exception of aquatic plants that have contributed some important new records to the Doñana Catalogue: Althenia orientalis (García Murillo \& Talavera, 1986), Callitriche lusitanica (Pizarro, 1990), Zannichellia obtusifolia (Talavera et al., 1986, Lemna trisulca, and Spirodella polyrhyza (García Murillo et al., 1991), etc. (Table. 1).

In terms of the "other" plant groups included in aquatic macrophytes, i.e., Charophyta and Bryophyta, data on these are more scarce and inconsistent.

The first records of Charophyta were noted by Corillion (1961), who included two of Doñana's Charophyta species in his work on southern Spain and North Africa charophytes: Chara connivens and Nitella flexilis. Some years later, Comelles (1982) and Sánchez (1984) added two more taxa to the list: Tolypella hispanica and Chara fragifera, respectively. Almost one decade later García Murillo et al. (1993) added nine new records to Doñana's charophyte catalogue. Finally, the most recent records are on Chara vulgaris var. oedophylla and Tolypella salina, referenced by Espinar et al. (1997).

In the Bryophytes group, there are two papers on the Riella genus (Cirujano et al., 1988 and 1992); Riccia fluitans and Ricciocarpos natans were mentioned by Rivas Martínez et al. (1980) and Sphagnum inundatum by García Murillo et al. (1995).

Table 1 shows the complete and current catalogue of Doñana's submerged macrophytes. It includes 74 taxa (21 more than those related in 1993 by García Murillo et al.) of which 46 are Spermatophyta (62\%), 3 Pteridophyta (4\%), 6 Bryophyta (8\%) and 19 Chlorophyta (26\%). Besides, this table points to the first floristic record of each taxon.

Table 1. Catalogue of aquatic macrophytes of Doñana protected areas. Catálogo de los macrófitos acuáticos de los espacios protegidos de Doñana.

\section{TAXA*} FIRST RECORD

CHLOROPHYTA

Characeae

Characeae

Characeae
Chara aspera Deth. ex Willd. var. aspera

Chara canescens Desv. \& Lois.

Chara connivens Salmz. ex A. Braun
García Murillo, Bernués \& Montes, 1993

García Murillo, Bernués \& Montes, 1993

Corrillion, 1961 
Table 1. Continued. Continuación.

\section{CHLOROPHYTA}

$\begin{array}{ll}\text { Characeae } & \text { Chara fragifera Durieu } \\ \text { Characeae } & \text { Chara fragilis Desv. } \\ \text { Characeae } & \text { Chara galioides DC. } \\ \text { Characeae } & \text { Chara hispida } \text { L. } \\ \text { Characeae } & \text { Chara vulgaris L. var. vulgaris } \\ \text { Characeae } & \text { Chara vulgaris L. var. contraria } \\ & \text { (A. Braun ex Kütz.) J. A. Moore } \\ \text { Characeae } & \text { Chara vulgaris L. var. oedophylla } \\ & \text { (Feldman) R. D. Wood } \\ \text { Characeae } & \text { Chara vulgaris L. var. longibracteata (Kütz.) } \\ & \text { J. Groves \& Bullock-Webster } \\ \text { Characeae } & \text { Lamprothamnium papulosum (Wallr.) J. Groves } \\ \text { Characeae } & \text { Nitella flexilis } \text { (L.) C. Agardh } \\ \text { Characeae } & \text { Nitella hyalina } \text { (DC.) C. Agardh } \\ \text { Characeae } & \text { Nitella tenuisissima } \text { (Desv.) Kütz. } \\ \text { Characeae } & \text { Nitella translucens } \text { (Pers.) C. Agardh } \\ \text { Characeae } & \text { Tollypella glomerata } \text { (Desv.) Leonh. } \\ \text { Characeae } & \text { Tollypella hispanica Nordst. ex T.F. Allen } \\ \text { Characeae } & \text { Tollypella salina Corillion }\end{array}$

Sánchez, 1984

Fernández Zamudio et al. (2006)

García Murillo, Bernués \& Montes, 1993

Van Vierssen et al., 1982

García Murillo, Bernués \& Montes, 1993

Fernández Zamudio et al. (2006)

Espinar et al., 1997

Fernández Zamudio et al. (2006)

García Murillo, Bernués \& Montes, 1993

Corrillion, 1961

García Murillo, Bernués \& Montes, 1993

García Murillo, Bernués \& Montes, 1993

García Murillo, Bernués \& Montes, 1993

García Murillo, Bernués \& Montes, 1993

Comelles, 1982

Espinar et al., 1997

\section{BRYOPHYTA}

$\begin{array}{lll}\text { Ricciaceae } & \text { Riccia fluitans } \text { L. } & \text { Rivas-Martínez et al., } 1980 \\ \text { Ricciaceae } & \text { Ricciocarpos } \text { natans } \text { L. } & \text { Rivas-Martínez et al., } 1980 \\ \text { Riellaceae } & \text { Riella cossoniana } \text { Trabut } & \text { Cirujano et al., 1992a } \\ \text { Riellaceae } & \text { Riella helicophylla } \text { (Bory \& Mont.) Mont. } & \text { Cirujano } \text { et al., 1988 } \\ \text { Riellaceae } & \text { Riella } \text { notarisii } \text { (Mont.) Mont. } & \text { Cirujano } \text { et al., 1992a } \\ \text { Sphagnaceae } & \text { Sphagnum inundatum } & \text { García Murillo et al., 1995 }\end{array}$

\section{PTERIDOPHYTA}

\begin{tabular}{|c|c|c|}
\hline $\begin{array}{l}\text { Azollaceae } \\
\text { Isoetaceae } \\
\text { Marsileaceae }\end{array}$ & $\begin{array}{l}\text { Azolla filiculides Lam. } \\
\text { Isoetes velatum A. Braun subsp. velatum } \\
\text { Marsilea strigosa Willd. }\end{array}$ & $\begin{array}{l}\text { Cobo et al., } 2003 \\
\text { Galiano \& Cabezudo, } 1976 \\
\text { Fernández Zamudio et al. (2006) }\end{array}$ \\
\hline \multicolumn{3}{|c|}{ SPERMATOPHYTA } \\
\hline Apiaceae & Apium inundatum $\mathrm{L}$. & Allier \& Bresset, 1975 \\
\hline Apiaceae & Oenanthe fistulosa $* * \mathrm{~L}$. & Cabezudo, 1975 \\
\hline Apiaceae & Thorella verticillatinundata** (Thore) Briq. & Cabezudo, 1974 \\
\hline \multirow[t]{2}{*}{ Apiaceae } & Oenanthe globulosa** L. & Cabezudo, 1975 \\
\hline & Carum verticillatum** (L.) Koch & Galiano \& Cabezudo, 1976 \\
\hline Apiaceae & Eryngium corniculatum** L. & Cabezudo, 1974 \\
\hline Apiaceae & Eryngium galiodes** Lam & Cabezudo, 1978 \\
\hline Callitrichaceae & $\begin{array}{l}\text { Callitriche truncata Guss. subsp. occidentalis } \\
\text { (Rouy) Schotsman }\end{array}$ & Castroviejo et al., 1980 \\
\hline Callitrichaceae & Callitriche lusitanica Schotsman & Pizarro, 1990 \\
\hline Callitrichaceae & Callitriche stagnalis Scop. & García Murillo, Bernués \& Montes, 1993 \\
\hline Callitrichaceae & Callitriche brutia Petagna & Castroviejo et al., 1980 \\
\hline Callitrichaceae & Callitriche obtusangula Le Gall & Fernández Zamudio et al. (2006) \\
\hline Ceratophyllaceae & Ceratophyllum demersum $\mathrm{L}$. & Mazaranov, 1967 \\
\hline Cyperaceae & Scirpus fluitans L. & Rivas-Martínez et al., 1980 \\
\hline
\end{tabular}


Table 1. Continued. Continuación.

\begin{tabular}{|c|c|c|}
\hline \multicolumn{3}{|l|}{ SPERMATOPHYTA } \\
\hline Elatinaceae & Elatine alsinastrum $\mathrm{L}$. & Mazaranov, 1967 \\
\hline Elatinaceae & Elatine macropoda Guss. & Mazaranov, 1967 \\
\hline Elatinaceae & Elatine hexandra (Lapierre) DC. & Cabezudo, 1975 \\
\hline Halogaraceae & Myriophyllum alterniflorum DC. & Mazaranov, 1967 \\
\hline Halogaraceae & Myriophyllum spicatum $\mathrm{L}$. & Van Vierssen et al., 1982 \\
\hline Hydrocharitaceae & Hydrocharis morsus-ranae $\mathrm{L}$. & Cabezudo, 1978 \\
\hline Juncaceae & Juncus heterophyllus Dufour & Galiano \& Cabezudo, 1976 \\
\hline Lemnaceae & Lemna gibba L. & Galiano \& Cabezudo, 1976 \\
\hline Lemnaceae & Lemna trisulca $\mathrm{L}$. & García Murillo et al., 1991 \\
\hline Lemnaceae & Lemna minor $\mathrm{L}$. & Mazaranov, 1967 \\
\hline Lemnaceae & Spirodella polyrhiza (L.) Schleiden & García Murillo et al., 1991 \\
\hline Lemnaceae & Wolffia arrhiza (L.) Horkel ex Wimmer & García Murillo, 2000 \\
\hline Lentibulariaceae & Utricularia exoleta $\mathrm{R}$. Br. & Castroviejo et al., 1980 \\
\hline Lentibulariaceae & Utricularia australis $\mathrm{R}$. Br. & Cabezudo, 1975 \\
\hline Nymphaeaceae & Nuphar luteum L. & Castroviejo et al., 1980 \\
\hline Nymphaeaceae & Nymphaea alba $\mathrm{L}$. & Castroviejo et al., 1980 \\
\hline Polygonaceae & Polygonum amphibium L. & Castroviejo et al., 1980 \\
\hline Potamogetonaceae & Potamogeton natans L. & Galiano \& Cabezudo, 1976 \\
\hline Potamogetonaceae & Potamogeton polygonifolius Pourret & Castroviejo et al., 1980 \\
\hline Potamogetonaceae & Potamogeton lucens L. & Mazaranov, 1967 \\
\hline Potamogetonaceae & Potamogeton trichoides Charm. \& Schlecht. & Cabezudo, 1978 \\
\hline Potamogetonaceae & Potamogeton crispus L. & Mazaranov, 1967 \\
\hline Potamogetonaceae & Potamogeton pectinatus $\mathrm{L}$. & Mazaranov, 1967 \\
\hline Ranunculaceae & Ranunculus tripartitus DC. & Cabezudo, 1978 \\
\hline Ranunculaceae & $\begin{array}{l}\text { Ranunculus peltatus subsp baudotii } \\
\text { (Godron) Meikle ex C. D. K. Cook }\end{array}$ & Allier \& Bresset, 1975 \\
\hline Ranunculaceae & $\begin{array}{l}\text { Ranunculus peltatus subsp saniculifolius } \\
\text { (Viv.) C. D. K. Cook }\end{array}$ & Pizarro, 1993 \\
\hline Ranunculaceae & $\begin{array}{l}\text { Ranunculus peltatus Schrank subsp fucoides } \\
\text { (Freyn) Muñoz Garmendia }\end{array}$ & Cirujano et al., 1992b \\
\hline Ruppiaceae & Ruppia maritima L. var. maritima & Cabezudo, 1978 \\
\hline Ruppiaceae & Ruppia drepanensis Tineo & Castroviejo et al., 1980 \\
\hline Zanichelliaceae & $\begin{array}{l}\text { Althenia orientalis (Tzvelev) } \\
\text { García Murillo \& Talavera }\end{array}$ & García Murillo \& Talavera, 1986 \\
\hline Zanichelliaceae & $\begin{array}{l}\text { Zannichelllia obtusifolia Talavera, } \\
\text { García \& Smith }\end{array}$ & Talavera et al., 1986 \\
\hline Zosteraceae & Zostera noltii Hornem & Castroviejo et al., 1980 \\
\hline
\end{tabular}

\section{SECOND STEP: AQUATIC MACROPHYTES AND ENVIRONMENTAL FACTORS}

At the end of the 1970s, González Bernáldez directed a series of studies on the relationship between the plants in Donaña and the environment (see García Novo, 1997). In this context, there was practically no mention of aquatic plants, with just one study found on the marsh's vegetation (Allier \& Bresset, 1977). In 1980, Rivas Martínez et al. published an excellent work on the vegetation in the Doñana National Park, in which they carried out a detailed phytosociological analysis of the different communities of plants in this protected natural area. Nevertheless, despite the superior quality of the research done, the informa- 
tion on aquatic plant communities was insufficient (as can be deduced from the chorological changes after 1980, included in Table 1).

In the $90 \mathrm{~s}$, in response to researches by Montes on Donaña's aquatic ecosystems, new data appeared on the ecology of aquatic plants in the area: data was published on their biomass (Duarte et al. 1990); the main factors (flooding time and salinity) controlling the distribution of these plants in Doñana's wetlands were identified (Bernués, 1990; Duarte et al., 1990); and a study was done on the marsh's seed bank (Grillas et al., 1993). Santamaría (Santamaría, 1995; Santamaría \& Hootsmans, 1998; Santamaría et al., 1995; 1996), under the direction of Montes and with samples collected from Doñana, also carried out a series of studies on the autoecology of Ruppia drepanensis Tineo, one of the most abundant underwater macrophytes in the Doñana salt marsh. In this same period, Serrano \& Toja (1995), working in sand lagoons of Doñana, related the presence of some aquatic macrophytes with other ecological parameters.

And finally, more recent works by Espinar (2004) and Espinar et al. (2002) have contributed valuable information on the salt marsh aquatic macrophytes in relation to their environment and to communities of helophytes.

\section{Studies on Seed Dispersal}

At the turn of the century, and as a result of the multidisciplinary approach taken by the Doñana Biological Station to environmental processes and with the involvement of Santamaría, a series of studies appeared on the role of birds in the passive transport of organisms. To be sure, a large number of these studies focused on the dispersal of aquatic macrophyte seeds by aquatic birds (Charalambidou et al., 2003; Green et al., 2002; Figuerola \& Green, 2002 and 2004; Figuerola et al., 2002; 2003 and 2005). These researches have been consolidated as a line of work, which is currently being carried out in the Doñana Biological Station under the direction of Green, with outstanding results. Likewise, Espinar et al. (2004) have recently published studies in this area.

\section{Aquatic Plants and Climate Change}

As stated in the introduction to this paper, a site's flora is one of the best natural sources of information on that area. This fact is even more perceptible in aquatic plants since their reaction to environmental changes (due to their particular physiology) is much faster and precise. Based on this premise, recent studies carried out in the eastern part of Doñana National Park and in the park's lagoons have shown how useful diachronic studies on the presence and distribution of aquatic plants can be in detecting climatic changes within relatively recent timeframes. The work of Sousa (2004) and Sousa \& García Murillo (1998; 1999; 2003 and 2005) illustrate this fact and find an explanation for the processes of aridization and desiccation of the coastal wetlands of Huelva Province by linking these processes to the end of the Little Ice Age, using -among other thingsthe presence of certain species of aquatic plans, the distribution of vegetation in the wetlands, and their changes over time.

\section{THIRD STEP: REGARDING CONSERVATION}

The uniqueness of the diverse species of aquatic macrophytes found in south-western Europe has been pointed out by some authors (Cook, 1983; García Murillo, 2003; Montes \& Martino, 1987); the majority of these taxa are located in the Doñana area. The work of Cirujano et al. (1992b) is noteworthy here in its ranking of Spanish wetlands based on the presence of certain species of macrophytes; the Doñana salt marsh was ranked second among all wetlands considered. ${ }^{1}$

In addition, in the late $1990 \mathrm{~s}$, the Andalusian Regional Environmental Agency (later, the Environmental Council) started a line of research aimed at identifying the biology of the plant species most at risk from a conservation standpoint.

\footnotetext{
1 In the work cited, the authors did not consider the Doñana lagoons or the changes in flora, which occurred after the work's publication, which clearly would have significantly increased the ranking of this area.
} 
The most salient outcomes of these studies were the "Andalusian Plant Species Red List (Decreto 104/1994; Ley 8/2003)" and two volumes compiling the most significant information on the species selected (Blanca et al., 1999-2000). In contrast to previous Spanish "Red Lists" (ICONA, 1987), this one included a significant number of aquatic species, as well as Althenia orientalis, Hydrocharis morsus-ranae, Utricularia exoleta, Wolffia arrhiza, Marsilea strigosa, and Thorella verticillatainundata (García Murillo, 2000; Silvestre, 2000), found in the Doñana area.

This was followed, as proposed by the Ministry of Environment, by numerous studies intended to update the "Red List" (ICONA, 1987) nationally. These studies were compiled in the AFA Project (Bañares et al., 2003), including the red list and the most relevant data from the research done on the different species, although it was not possible to study some of the species listed. The AFA red list includes two aquatic macrophyte species found in Doñana (Utricularia exoleta and Hydrocharis morsus-ranae).

The surveys and research carried out for the Red Lists generated numerous articles which highlighted the state of some species of aquatic macrophytes. Included among such articles were those of Cirujano et al. (1998) and García Murillo et al. (2000) on species found in the Doñana protected area.

\section{Exotic Organisms}

The early 1980s brought the detection of the first exotic organisms in Doñana (García Murillo et al., 2004b). The first of such invaders was the American crawfish (Procambarus clarckii) and its spectacular proliferation. The ability of $P$. clarckii to physically transform its environment and alter the availability of resources for other species in the aquatic ecosystems in which it was introduced, deeply concerned environmentalists and scientists. Its effect upon macrophyte communities was tremendous, given that they are its principal food source. After the initial period of crawfish expansion, numerous Doñana macrophyte communities were simply dwindling, with some species wiped out due to the activity of this animal (Bravo et al., 1993; Duarte et al., 1990; García Murillo et al., 1993). The numerous studies on $P$. clarkii, undertaken by the UAM (Universidad Autónoma of Madrid) research team headed by Montes, have emphasised the fact that it is now a key element in most of the aquatic ecosystems in Doñana and a significant control factor when it comes to aquatic macrophyte populations in this protected area (Bravo et al., 1993; Gutiérrez-Yurrita et al., 1998).

Likewise, the Azolla filiculoides species -a floating pteridophyte native to the New Worldbegan to appear in the Doñana marsh in the early part of the $21^{\text {st }}$ century (Cobo et al., 2003 and García Murillo et al., 2004a). In just a couple of years, its presence has extended over nearly the entire marsh, forming carpets sometimes reaching $10 \mathrm{~cm}$ thick, which can be clearly seen from the RBD (Doñana's Biological Reserve) plane used for bird surveys. These carpets prevent the sun's rays from reaching the water below, thereby making it impossible for submerged macrophytes (nearly all present in this area) to develop. They also increase eutrophyzation since they can fix nitrogen, and their respiratory activity consumes the oxygen in the water below (García Murillo et al. 2004a). Just as with the American red crawfish, the changes in the aquatic ecosystems of Doñana attributable to Azolla filiculoides may be dramatic. The attempts to control it have, to date, been futile (García Murillo et al., 2004b).

Finally, in December of 2004, the tropical neophyte Pistia stratiotes was found in some irrigation canals located in the Doñana Park in the area of Sanlúcar de Barrameda covering $3 \mathrm{Km}$ of canals (García Murillo et al., 2005a). Thanks to the quick intervention of the Andalusian Regional Council on the Environment -faced with the risk posed by this new invasion to the Doñana protected areas- and the low temperatures in January 2005, the Pistia carpets were eliminated (García Murillo et al., 2005b). Nevertheless, the risk continues to exist since some of the Pistia plants sampled had flowers and seeds, and it is well-known that the seeds of this species can remain functional for long periods of time buried under the water. 


\section{CONCLUSIONS}

In the time span since the publication of the last floristic catalogue on the Doñana area, numerous references whose primary or secondary objective is the study of Doñana's aquatic macrophytes can be cited, although they are few in comparison to existing information on other in the same area.

With regard to the catalogue on aquatic macrophytes, we believe it is completed except for the addition of new exotic plants whose effects encompass this natural area (Cobo et al., 2003), and the withdrawal of others -cited by $20^{\text {th }}$-century researchers- which have disappeared due to the deterioration in water quality and the pressure of the environment surrounding this protected natural area.

The regional administration -and to a lesser extent the national one- has taken this situation into account, by including some of the aquatic macrophytes in its red list of species in danger of extinction. Nevertheless, the number of taxa which should be included in the list is greater (see Cobo et al., 2002).

Moreover, the importance of this area for the conservation of aquatic macrophytes is evident since it contains numerous species of aquatic macrophytes, many of which are limited-area species ("endemic species"), relatively uncommon in aquatic plants.

Along the same lines, a conflict has arisen in the area's flora conservation-management, fully affecting the group of aquatic plants: many of the aquatic macrophyte species found in Doñana cover wide areas of distribution (in theory); however (in reality) these areas are largely fragmented, with similarly fragmented populations. These species should be included in the red lists, since their vulnerability is quite high, a fact which has been ignored by environmentalists when it comes to the (theoretical) distribution areas of these species.

As studies are concerned on aquatic macrophytes and how they relate to environmental factors, while there are a number of quality studies on this subject, more work on the basic aspects of this relationship would be of value (e.g., how macrophytes relate to nutrients, factors determining macrophyte distribution, studies on succession, etc.). Finally, attention must be called to the deterioration of Doñana's waters, the effects of which operate on two levels:

1. By causing the disappearance of so-called "difficult environment" specialist plants that had taken refuge in this natural setting (such as plants from bogs or oligotrophic wetlands)

2. By facilitating the invasion of exotic species, some of which have great potential for habitat modification and its consequences.

A question remains: Is there still time for us to comprehend the full complexity of the native aquatic systems of Doñana or are the transformations detected in recent years the beginning of an irreversible process that will profoundly change this place?

\section{ACKNOWLEDGMENTS}

These studies were supported by the Project Doñana 2005 from the Spain Environmental Ministry.

\section{BIBLIOGRAPHY}

ALLIER, C. et V. BRESSET. 1975. La vegetation des milieux sales de la Reserve Biologique de Doñana (Bas Guadalquivir, Espagne). Colloques phytosociologiques, 4: 257-269.

ALLIER, C. et V. BRESSET. 1977. Etude phytotosociologique de la Marisma et de sa bordure (Reserve Biologique de Doñana). In: Doñana. Prospección e inventario de ecosistemas. F. García Novo, J. Merino, L. Ramírez Díaz, M. Ródenas, F. Sancho Royo, A. Torres, F. González Bernáldez, F. Díaz Pineda, C. Allier, V. Bresset \& A. Lacoste (eds.): 59-110. ICONA. Monografía $n^{\circ} 18$. Ministerio de Agricultura. Madrid.

BAÑARES, A., G. BLANCA, J. GÜEMES, J.C. MORENO SANZ \& S. ORTIZ. 2003. Atlas y libro rojo de la flora vascular amenazada de España. Ministerio de Medio Ambiente. Madrid. 1027 pp.

BERNUÉS, M. 1990. Limnología de los sistemas acuáticos superficiales del Parque Nacional de 
Doñana. Tésis Doctoral. Universidad Autónoma de Madrid. 242 pp.

BLANCA, G., B. CABEZUDO, J. E. HERNÁNDEZBERMEJO, C. M. HERRERA, J. MUÑOZ \& B. VALDÉS (eds.) 1999-2000. Libro rojo de la Flora silvestre amenazada de Andalucia.Tomo I: Especies en peligro de extinción. Tomo II: Especies vulnerables. Consejería de Medio Ambiente. Sevilla. Tomo I, $302 \mathrm{pp}$; tomo II, $375 \mathrm{pp}$.

BRAVO, M. A., C. DUARTE \& C. MONTES. 1994. Environmental factors controlling the life history of Procambarus clarkii (Decapoda, Cambaridae) in a temporary marsh of the Doñana National Park (SW. Spain). Verh. Int. Verein. Limnol., 25:2450-2453.

CABEZUDO, B. 1974. Nota corológica sobre la flora de Huelva. Lagascalia, 4(2): 281-284.

CABEZUDO, B. 1975. Nota corológica sobre la flora de Huelva II. Lagascalia, 5(1): 77-83.

CABEZUDO, B. 1978. Plantas de la Reserva Biológica de Doñana II. Lagascalia, 8(2): 166-182.

CASTROVIEJO, S., E. VALDÉS-BERMEJO, S. RIVAS-MARTÍNEZ \& M. COSTA. 1980. Novedades florísticas de Doñana. Anales Jardín Botánico de Madrid, 36: 203-244.

CHARALAMBIDOU I. C., L. SANTAMARÍA \& O. LANGEVOORD. 2003. Effect of ingestion by five duck dispersers on the retention time, retrieval and germination of Ruppia maritima seeds. Functional Ecology, 17: 747-753.

CIRUJANO, S., C. MONTES, P. MARTINO, S. ENRIQUEZ \& P. GARCÍA MURILLO. 1988. Contribución al estudio del género Riella Mont. (Sphaerocarpales, Riellaceae) en España. Limnetica 4: 41-50.

CIRUJANO, S., C. FRAILE \& P. GARCÍA MURILLO. 1992a. Notas sobre el género Riella Mont. Anales Jardín Botánico de Madrid, 50(1): 113-115.

CIRUJANO, S. M. VELAYOS, F. CASTILLA \& M. GIL. 1992b. Criterios botánicos para la valoración de las lagunas y humedales españoles (Península Ibérica e Islas Baleares). ICONA. Madrid. $456 \mathrm{pp}$.

CIRUJANO, S., L. MEDINA, P. GARCÍA MURILLO \& J. L. ESPINAR. 1998. Ricciocarpos natans (L.) Corda (Ricciaceae) en la Península Ibérica. Anales Jardín Botánico de Madrid 56: 366-368.

COBO, M. D., SÁNCHEZ GULLÓN, E. \& GARCÍA MURILLO, P. 2002. Flora y Vegetación. In: Parque Nacional de Doñana. V. García Canseco .: 108174. Canseco Editores SL. Talavera de la Reina.

COBO, M. D., E. SÁNCHEZ GULLÓN \& P. GARCÍA MURILLO. 2003. Datos acerca de la presencia y gestión de especies invasoras y xenófitas en un espacio protegido europeo paradigmático. In: Contribuciones al conocimiento de las especies invasoras en España. L. Capdevilla Argüelles, B. Zilletti \& N. Pérez Hidalgo, N. (eds.): 38-41. GEI. León.

COMELLES, M. 1982. Noves localitat i revisió de la distribució de les espéces de carófits a Espanya. Tesis de Licenciatura. Universidad Central de Barcelona. 132 pp.

COOK, C. D. K. 1983. Aquatic plants endemic to Europe and the Mediterranean. Botanische Jahrbücher Syst., 103: 539-582

CORILLION, R. 1961. Les vegetations précoces des Charophycées d'Espagne Meridionale et du Maroc Occidental. Revue Générale de Botanique, 68: 317-330.

DECRETO 104/1994, de 10 de Mayo (BOJA de 14 de Julio): Catálogo Andaluz de Especies de Flora Silvestre amenazada: 1-9.

DUARTE, C., C. MONTES, S. AGUSTI, P. MARTINO, M. BERNUES \& J. KALFF. 1990. Biomasa de macrofitos acuaticos en la marisma del Parque Nacional de Donana (SO. España): importancia and factores ambientales que controlan su distribucion. Limnetica, 6: 1-12.

ESPINAR, J. L. 2000. Distribución espacial y temporal de las comunidades de macrófitos acuáticos de la Marisma Salada del Parque Nacional de Doñana. Tesis de Licenciatura. Universidad de Sevilla. $126 \mathrm{pp}$.

ESPINAR, J. L. 2004 Ecología de las comunidades de grandes helófitos de la marisma del Parque Nacional de Doñana. Tesis Doctoral. Universidad de Sevilla . 214 pp.

ESPINAR, J. L., S. CIRUJANO y P. GARCÍA MURILLO. 1997. Contribución al conocimiento de los carófitos del Parque Nacional de Doñana. Acta Botánica Malacitana, 22: 209-211.

ESPINAR J. L., L. V. GARCÍA,.P. GARCÍA MURILLO \& J. TOJA. 2002. Submerged macrophyte zonation in a Mediterranean salt marsh: a facilitation effect from estabilished helophytes? Journal of Vegetation Science, 13: 1- 15.

ESPINAR, J. L., L. V. GARCÍA, J. FIGUEROLA, A. J. GREEN \& L. CLEMENTE. 2004. Helophyte germination in a Mediterranean coastal marsh: Gut-passage by ducks changes seed response to salinity. Journal of Vegetation Science, 15: 315-322.

FERNÁNDEZ ZAMUDIO, R., S. CIRUJANO, I. NIETO, A. SOUSA \& P. GARCÍA MURILLO. 
2006. Novedades florísticas en el Parque Nacional de Doñana. Acta Botánica Malacitana.

FIGUEROLA, J. \& A. J. GREEN. 2002. How frequent is external transport of seeds and invertebrate eggs by waterbirds? A study in Doñana, SW Spain. Archiv für Hydrobiologie, 155: 557-565

FIGUEROLA, J. \& A. J. GREEN. 2004. Effects of seed ingestion and herbivory by waterfowl on seedling establishment: a field experiment with wigeongrass Ruppia maritima in Doñana, south-west Spain. Plant Ecology, 173: 33-38.

FIGUEROLA, J., A. J. GREEN \& L. SANTAMARIA. 2002. Comparative dispersal effectiveness of wigeongrass seeds by waterfowl wintering in south-west Spain: quantitative and qualitative aspects. Journal of Ecology, 90: 989-1001

FIGUEROLA J., A. J. GREEN \& L. SANTAMARIA. 2003. Passive internal transport of aquatic organisms by waterfowl in Doñana, south-west Spain. Global Ecology and Biogeography, 12: 427-436.

FIGUEROLA, J., L. SANTAMARIA, A. J. GREEN, I. LUQUE, R. ALVAREZ \& I. CHARALAMBIDOU. 2005. Endozoochorous dispersal of aquatic plants: does seed gut passage affect plant performance? American Journal of Botany, 92: 696-699.

GALIANO, E. F. \& B. CABEZUDO. 1976. Plantas de la Reserva Biológica de Doñana (Huelva). Lasgascalia, 6: 117-176.

GARCÍA MURILLO, P. 2000. Althenia orientalis; Hydrocharis morsus-ranae; Utricularia exoleta y Wolffia arrhiza. In: Libro Rojo de la Flora Silvestre Amenazada de Andalucía. TomoII. G. Blanca, B. Cabezudo, J. E. Hernández-Bermejo, C. M. Herrera, J. Muñoz \& B. Valdés (eds.): 3134; 173-177; 361-363 \& 373-375. Consejería de Medio Ambiente. Junta de Andalucía. Sevilla.

GARCÍA MURILLO, P. 2003. Macrófitos acuáticos en los humedales andaluces. Medio Ambiente, 42: 38-41

GARCÍA MURILLO, P. \& S. TALAVERA. 1986. el Género Althenia Petit. Lagascalia, 14: 102-114.

GARCÍA MURILLO, P. S. CIRUJANO \& M. BERNUES. 1991. Lemna trisulca L. y Spirodella polyrhiza (L.) Scheiden, nuevas para el sur de la Península Ibérica. Anales Jardín Botánico de Madrid, 48: 268-270.

GARCÍA MURILLO, P., M. BERNÚES, \& C. MONTES, 1993. Los macrofitos acuáticos del Parque Nacional de Doñana (SW España). Aspectos florísticos. Actas VI Congreso Español de Limnología, 261-267.
GARCÍA MURILLO, P., A. SOUSA \& E. FUERTES. 1995. Sphagnum inumdatum Russ., nuevo para Andalucía. Anales Jardín Botánico de Madrid, 53: 245-245.

GARCÍA MURILLO, P., S. CIRUJANO, L. MEDINA, \& A. SOUSA. 2000 ¿Se extinguirá Hydrocaris morsus ranae L. de la Península Ibérica? Portugaliae Acta Biológica, 19: 149-158.

GARCÍA MURILLO, P., M. D. COBO, E. SÁNCHEZ GULLÓN \& H. GARRIDO. 2004a. Una planta acuática americana invade Doñana. Quercus, 218: 46- 47.

GARCÍA MURILLO, P., M. D. COBO, E. SÁNCHEZ GULLÓN \& H. GARRIDO. 2004b. Plantas exóticas e invasoras en Doñana. Medio Ambiente, 46: 45-53.

GARCÍA MURILLO, P., E. DANA SÁNCHEZ, \& C. RODRÍGUEZ. 2005a. Pistia stratiotes L. (Araceae) una planta acuática exótica en las proximidades del Parque Nacional de Doñana (SW España). Acta Botánica Malacitana, 30: 235-236.

GARCÍA MURILLO, P., E. DANA SÁNCHEZ y C. RODRÍGUEZ HIRALDO. 2005b. La lechuga de agua amenaza con invadir Doñana. Quercus, 232: 36-37.

GARCÍA NOVO, F. 1997. The ecosystems of Doñana Nacional Park. In: The ecology and conservation of European dunes. F. García Novo, R. M. N. Carwford \& M.C. Díaz Barradas (eds.): 77116. Universidad de Sevilla. Sevilla.

GREEN A. J., J. FIGUEROLA, \& M. I. SÁNCHEZ 2002. Implications of waterbird ecology for the dispersal of aquatic organisms. Acta Oecologica, 23: 177-189

GRILLAS, P., P. GARCÍA MURILLO, O. GEERTZHANSEN, N. MARBÁ, C. MONTES, C. M. DUARTE, L. TAM HAM, A. GROSSMAN. 2000. Submerged macrophyte seed bank in a Mediterranean temporary marsh: abundance and relationship with established vegetation. Oecologia, 94: 1-6.

GUTIÉRREZ-YURRITA, P. J., G. SANCHO, M. A. BRAVO-UTRERA, A. BALTANÁS \& C. MONTES. 1998. Diet of the red swamp crayfish Procambarus clarkii in natural ecosystems of the Doñana National Park temporary fresh-water marsh (Spain) Journal of Crustacean Biology, 18(1): 120-127.

ICONA. 1987. Libro rojo de las especies vegetales amenazadas de España peninsular e islas Baleares. ICONA-MAPA. Madrid. 676 pp.

LEY 8/2003, de 28 de Octubre (BOJA de 12 de Noviembre): Ley de la flora y fauna silvestres. 
MAZARANOV, V. 1967. Ostracodes, cladocères, hétéroptères et hydracariens nouveaux pour les marismas du Guadalquivir (Andalousie). Données écologiques. Anales de Limnologie, 3(1): 47-64.

MONTES, C. \& P. MARTINO. 1987. Las lagunas salinas españolas. In: Bases científicas para la protección de humedales en España: 95-145. Real Acad. Ciencias Exactas, Físicas y Naturales. Madrid.

PIZARRO, J. M. 1990. Asientos para un atlas corológico de la flora occidental. Mapa 420. Callitriche lusitanica Schotman. Fontqueria, 28: 142-144.

PIZARRO, J. M. 1993. Sistemática y ecología del subgénero Batrachium (DC.) A.Gray (Ranunculus L.) en el Sistema Central (Península Ibérica). Tesis doctoral. Universidad Complutense de Madrid. 320 pp.

RIVAS-MARTÍNEZ, S., M. COSTA, S. CASTROVIEJO \& E. VALDÉS. 1980. La vegetación de Doñana (Huelva, España). Lazaroa, 2: 5-189.

SÁNCHEZ, P. M. 1984. Contribción al conocimiento del género Chara en Andalucía. Acta Botánica Malacitana, 9: 79-84.

SANTAMARÍA, L. 1995. Ecology of Ruppia drepanensis Tineo in a Mediterranean brackish marsh (Doñana National Park, SW Spain). A basis for the management of semiarid floodplain wetlands. $\mathrm{PhD}$. Dissertation. Wageningen Agricultural University. Balkema, Rotterdam. 242 pp.

SANTAMARÍA, L., M. J. M. HOOTSMANS \& W. VAN VIERSSEN. 1995. Flowering time as influenced by nitrate fertilization in Ruppia drepanensis Tineo. Aquatic Botany, 52: 45-58.

SANTAMARÍA, L., C. MONTES \& M. J. M. HOOTSMANS. 1996. Influence of environmental parameters on the biomass development of Ruppia drepanensis populations in Doñana National Park: The importance of conditions affecting the underwater light climate. International Journal of Salt Lake Research, 5: 157-180.

SANTAMARÍA, L. \& M. J. M. HOOTSMANS. 1998. The effect of temperature on the growth, photosynthetic performance and reproduction of a mediterranean submerged macrophyte, Ruppia drepanensis. Aquatic Botany, 60: 169-188.

SERRANO, L. \& J. TOJA. 1995. Limnological description of four temporary ponds in the Doñana National Park. Arch. Hydrobiol., 133: 497-516.

SILVESTRE, S. 2000. Marsilea strigosa \& Thorella verticillatainundata. In Libro Rojo de la Flora Silvestre Amenazada de Andalucía. Tomo II. G. Blanca, G., B. Cabezudo, J. E. Hernández-Bermejo, C. M. HerrerA, J. Muñoz \& B. Valdés (eds.): 229231 y 352-354. Consejería de Medio Ambiente. Junta de Andalucía. Sevilla.

SOUSA, A. \& P. GARCÍA MURILLO. 1998 Cambios históricos en el avenamiento superficial y la vegetación del Parque Natural de Doñana (Sector Abalario). Ería, 46: 165-182.

SOUSA, A. \& P. GARCÍA MURILLO. 1999. Historical evolution of the Abalario lagoon complex (Doñana, Natural Park, SW Spain). Limnetica, 16: 85-98.

SOUSA, A. \& P. GARCÍA MURILLO. 2003 Changes in wetlands of Andalusia (Doñana Natural Park, SW Spain) at the end of the Little Ice Age. Climatic Change, 58: 193-217.

SOUSA, A. \&. P. GARCÍA MURILLO. 2005. Historia ecológica y evolución de las lagunas peridunares del Parque Nacional de Doñana. Organismo Autónomo Parques Nacionales. Ministerio de Medio Ambiente. Madrid. 169-170 pp.

SOUSA, A. 2004. Evolución de la vegetación hidrofítica y de los humedales continentales asociados en el litoral onubense oriental. Tesis Doctoral. Universidad de Sevilla. $550 \mathrm{pp}$.

TALAVERA, S., P. GARCÍA MURILLO \& H. SMIT. 1986. Sobre el género Zannichellia L. Lagascalia, 14(2): 241-271.

VAN VIERSSEN, V. \& R. J. VAN WIJK. 1982. On the identity and autoecology of Zannichellia peltata Bertol. in western Europe. Aquatic Botany, 12: 199-215.

VICIOSO, C. 1945. Notas sobre la Flora española. Anales Jardín Botánico Madrid, 6: 5-88. 